\title{
Attrition rates in neurosurgery residency: analysis of 1361 consecutive residents matched from 1990 to 1999
}

\author{
Gabrielle Lynch, ${ }^{1}$ Karina Nieto, BA, ${ }^{2}$ Saumya Puthenveettil, MS, ${ }^{1}$ Marleen Reyes, BA, ${ }^{1}$ \\ Michael Jureller, BS, ${ }^{1}$ Jason H. Huang, MD, ${ }^{3}$ M. Sean Grady, MD, ${ }^{4}$ Odette A. Harris, MD, MPH, ${ }^{5}$ \\ Aruna Ganju, MD, ${ }^{2}$ Isabelle M. Germano, MD, ${ }^{6}$ Julie G. Pilitsis, MD, PhD, ${ }^{7}$ Susan C. Pannullo, MD, ${ }^{8}$ \\ Deborah L. Benzil, MD, ${ }^{9}$ Aviva Abosch, MD, PhD, ${ }^{10}$ Sarah J. Fouke, MD, ${ }^{11}$ \\ and Uzma Samadani, MD, PhD'
}

'Department of Neurosurgery, New York University School of Medicine, New York, New York; 'Department of Neurosurgery, Northwestern University School of Medicine, Chicago, Illinois; ${ }^{3}$ Department of Neurosurgery, University of Rochester School of Medicine, Rochester, New York; ${ }^{4}$ Department of Neurosurgery, University of Pennsylvania School of Medicine, Philadelphia, Pennsylvania; ${ }^{5}$ Department of Neurosurgery, Stanford University School of Medicine, Palo Alto, California; ${ }^{6}$ Department of Neurosurgery, Mount Sinai School of Medicine, New York, New York; ' 7 Department of Neurosurgery, Albany Medical College, Albany, New York; ${ }^{8}$ Department of Neurosurgery, Weill Cornell Medical College, New York, New York; ${ }^{2}$ Department of Neurosurgery, Columbia University, New York, New York; ${ }^{10}$ Department of Neurosurgery, University of Colorado, Denver, Colorado; and ${ }^{11}$ Department of Neurosurgery, Swedish Neuroscience Institute, Seattle, Washington

OBJECT The objective of this study is to determine neurosurgery residency attrition rates by sex of matched applicant and by type and rank of medical school attended.

METHODS The study follows a cohort of 1361 individuals who matched into a neurosurgery residency program through the SF Match Fellowship and Residency Matching Service from 1990 to 1999. The main outcome measure was achievement of board certification as documented in the American Board of Neurological Surgery Directory of Diplomats. A secondary outcome measure was documentation of practicing medicine as verified by the American Medical Association DoctorFinder and National Provider Identifier websites. Overall, 10.7\% $(n=146)$ of these individuals were women. Twenty percent $(n=266)$ graduated from a top 10 medical school $(24 \%$ of women [35/146] and $19 \%$ of men [232/1215], $p=$ $0.19)$. Forty-five percent $(n=618)$ were graduates of a public medical school, $50 \%(n=680)$ of a private medical school, and $5 \%(n=63)$ of an international medical school. At the end of the study, $0.2 \%$ of subjects $(n=3)$ were deceased and $0.3 \%(n=4)$ were lost to follow-up.

RESULTS The total residency completion rate was $86.0 \%(n=1171)$ overall, with $76.0 \%(n=111 / 146)$ of women and $87.2 \%(n=1059 / 1215)$ of men completing residency. Board certification was obtained by $79.4 \%(n=1081)$ of all individuals matching into residency between 1990 and 1999. Overall, 63.0\% (92/146) of women and 81.3\% (989/1215) of men were board certified. Women were found to be significantly more at risk $(p<0.005)$ of not completing residency or becoming board certified than men. Public medical school alumni had significantly higher board certification rates than private and international alumni (82.2\% for public [508/618]; $77.1 \%$ for private [524/680]; $77.8 \%$ for international [49/63]; $p<0.05)$. There was no significant difference in attrition for graduates of top 10-ranked institutions versus other institutions. There was no difference in number of years to achieve neurosurgical board certification for men versus women.

CONCLUSIONS Overall, neurosurgery training attrition rates are low. Women have had greater attrition than men during and after neurosurgery residency training. International and private medical school alumni had higher attrition than public medical school alumni.

http://thejns.org/doi/abs/10.3171/2014.10.JNS132436

KEY WORDS attrition; board certification; sex; neurosurgery residency

ABBREVIATIONS AAMC $=$ American Association of Medical Colleges; AANS $=$ American Association of Neurological Surgeons; ABNS $=$ American Board of Neurological Surgery; NPI = National Provider Identifier.

SUBMITTED November 2, 2013. ACCEPTED October 9, 2014.

INCLUDE WHEN CITING Published online November 21, 2014; DOI: 10.3171/2014.10.JNS132436.

DISCLOSURE The authors report no conflict of interest concerning the materials or methods used in this study or the findings specified in this paper. 
I N 1991, 40\% of medical school entrants were female; presently that number is $47 \% .^{4}$ Currently, however, only 236 of 4083 active board-certified neurosurgeons are female $(5.8 \%)$; this percentage was $5.9 \%$ in 2004 and actually decreased to $5.1 \%$ in 2006 (data provided by the American Association of Neurological Surgeons [AANS] and the American Board of Neurological Surgery [ABNS]). The percentage of women who are boardcertified neurosurgeons thus has not changed substantially in a decade; neurosurgical leadership has identified this as a problem requiring correction to optimize the potential of the neurosurgical workforce..$^{22}$

Board certification is a voluntary process. Upon completion of residency, a neurosurgeon becomes board eligible. After collecting independent surgical cases with more than 1 year of follow-up and several letters from boardcertified neurosurgeons attesting to competency, a boardeligible neurosurgeon must pass an oral examination to become certified by the ABNS. Some neurosurgeons continue to practice without ABNS certification or seek certification from other credentialing organizations.

The objective of this study is to determine the attrition rates from neurosurgical training programs and years from match to board certification, broken down by sex, institution type, and rating. Comparisons will be made to other surgical training specialties in the Discussion to identify factors that may impact attrition. This objective is undertaken to determine whether attrition rates for particular subsets of matched applicants, particularly women, are lower than those for other subsets. It is hoped that if a problem is identified by this work, future studies will focus on means of fixing it.

\section{Methods}

Institutional review board approval for the study was obtained from the New York Harbor Healthcare System.

A list of all individuals matching into neurosurgery residency from 1990 to 1999 inclusive, including the programs in which they matched and their prior medical schools, was obtained from the SF Match Fellowship and Residency Matching Service. Schools were divided into public versus private as classified by the American Association of Medical Colleges (AAMC) on its website (https://services.aamc.org/tsfreports/select.cfm?year_of_ study=2006). Schools were deemed international if they were not located in the US and did not appear on the AAMC list. Schools were considered "top 10" as determined by US News and World Report ranking performed the year of acceptance into residency for any given medical student.

Individuals were classified as having completed residency if they were confirmed by the American Medical Association DoctorFinder and individual practice websites to be practicing neurosurgery. Outcome data for board certification were obtained through the Directory of Diplomats provided by the ABNS. Additional location information was obtained using the National Provider Identifier (NPI; https://nppes.cms.hhs.gov/NPPESRegistry/ NPIRegistryHome.do), individual neurosurgical program websites, and the ancestry.com public information da- tabase search engine. Data regarding sex were acquired through the NPI registry site. Three individuals were confirmed dead through the above search engines with independent confirmation by at least one neurosurgeon, and 4 individuals were noted to be nonpracticing physicians in the US and were lost to follow-up.

This cohort was monitored until November 2013 to assess whether board certification was obtained. The algorithm used to determine current status of the 1361 matched residents is depicted in Fig. 1.

A 2-sample t-test was performed for comparison of duration of time (years) from match to board certification and comparison among attrition rates in public versus private medical school attendees. Chi-square analysis with Yates' continuity correction was performed for comparison of binomial variables (practicing neurosurgery or not; board certified or not); $p<0.05$ was considered significant.

Data analysis was performed using $\mathrm{R}$ Project version 3.0.1.

\section{Results}

Between 1990 and 1999, 1361 individuals matched into a neurosurgical residency program through the SF Match Fellowship and Residency Matching Service. Of these, $1081(79.4 \%)$ achieved board certification (Figs. 1 and 2) and $90(6.6 \%)$ were practicing neurosurgery without certification by the ABNS (Fig. 3). All of these individuals are presumed to have completed residency yielding a total residency completion rate of $86 \%$ overall.

Overall, 63.0\% $(\mathrm{n}=92 / 146)$ of women and $81.4 \%(\mathrm{n}=$ 989/1215) of men were board certified. Women were found to be significantly more at risk for not becoming board certified than men with an RR of 1.29 (95\% CI 1.14-1.47) and OR of 2.57 (95\% CI 1.78-3.70) $\left(\chi^{2}=25.85, p=3.693\right.$ $\left.\times 10^{-7}\right)$. The majority of female attrition occurred during residency; $76.0 \%$ ( $\mathrm{n}=111 / 146)$ of women and $87.2 \%(\mathrm{n}=$ 1059/1215) of men completed residency (RR for women $=$ 1.15 [95\% CI 1.05-1.26], OR 2.21 [95\% CI 1.45-3.34], $\chi^{2}$ $\left.=13.50, \mathrm{p}=2.389 \times 10^{-4}\right)$. The number of women starting residency in any given year who became board certified ranged from 7 to 12 , with a mean of 9.2 (Table 1).

Public medical school alumni had significantly higher board certification rates than private and international alumni $(82.2 \%$ for public [508/618], $77.1 \%$ for private [524/680], and 77.8\% for international [49/63]; $p=0.026$ for public vs private; public vs international and private vs international were not significant) (Fig. 4). Failure to achieve board certification was not dependent on graduating from a top 10 medical school for either men or women.

Thirteen of 35 females (37\%) who graduated from a top 10 medical school, and 40 of 109 females (37\%) not attending a top 10 medical school did not become board certified (not significant). For men the rates for failure to achieve board certification were 19\% (45/231) and 18\% (177/979) for those who had attended a top 10 medical school and those who had not, respectively (not significant). There was no significant difference in total attrition or board certification for graduates of top 10-ranked institutions versus other institutions.

The average number of years to achieve neurosurgical 


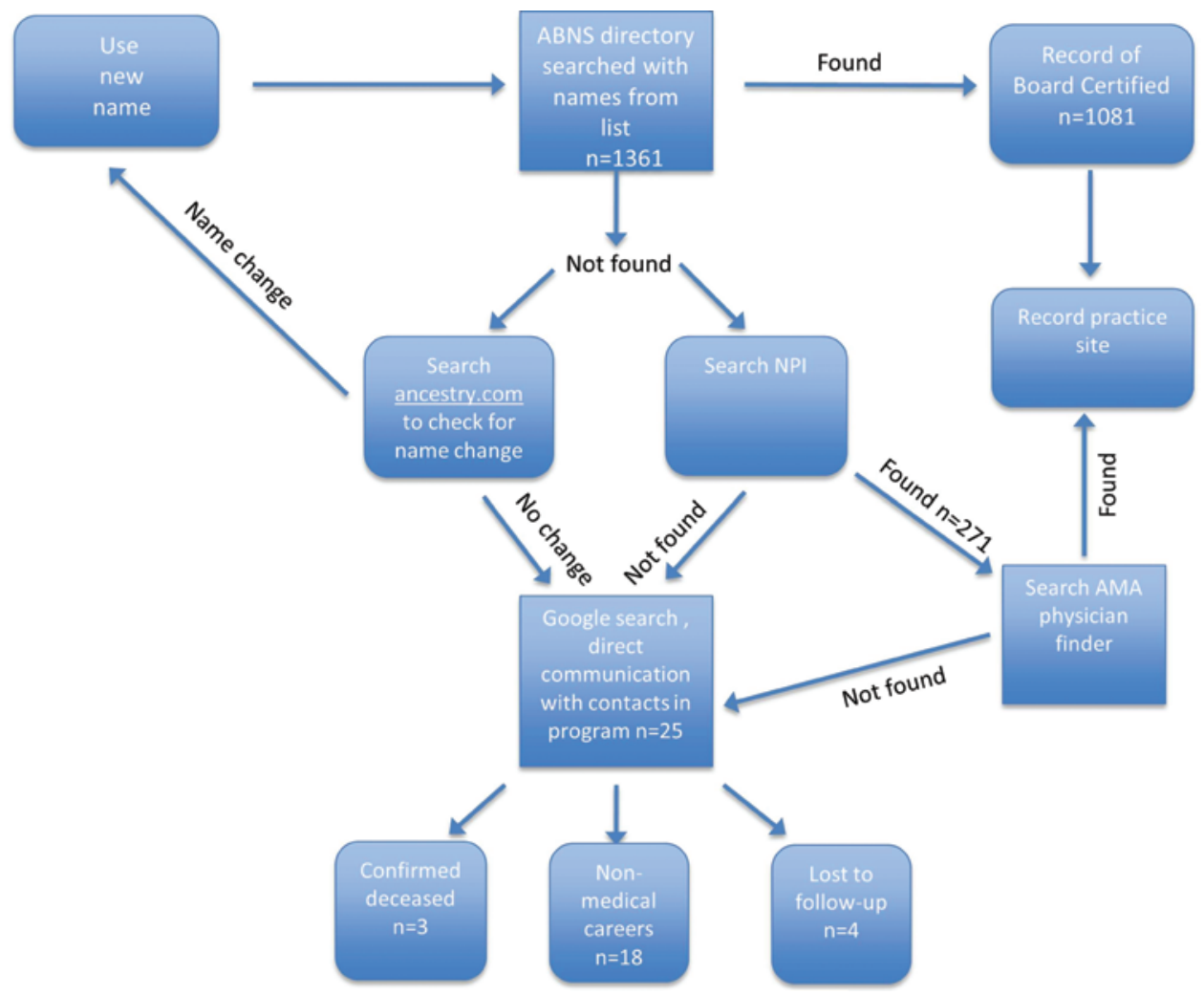

FIG. 1. A search algorithm was used to ascertain the status of the 1361 individuals matched into neurosurgery between 1990 and 1999. Figure is available in color online only.

board certification for men was 12.3 years and for women it was 12.5 years $(p=0.24,2$-sample t-test).

Fates of individuals who matched between 1990 and 1999 and did not become board certified are summarized in Table 2. Board certification rates by individual medical school attended are listed in Table 3 and by individual residency program in which each applicant was matched in Table 4.

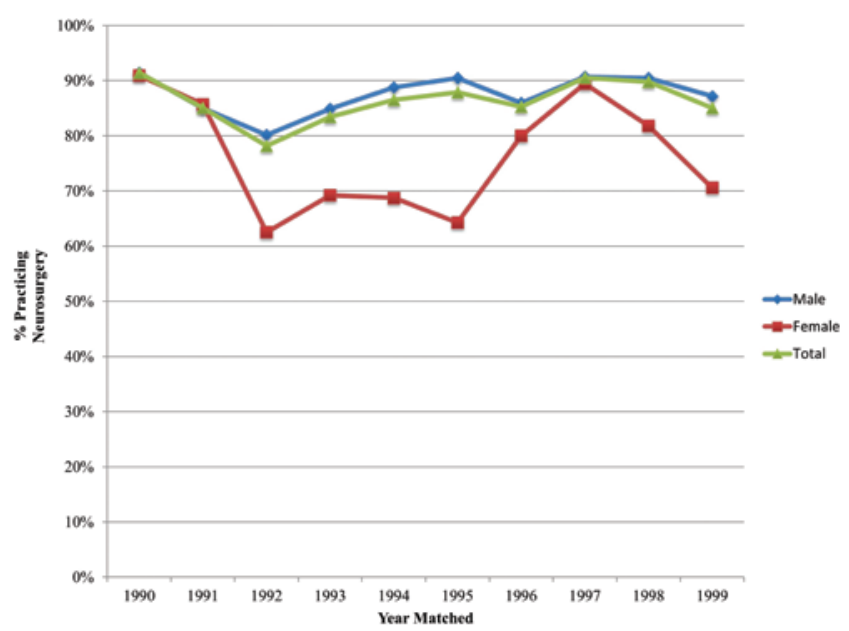

FIG. 2. The percentage of matched applicants from 1990 to 1999 who are practicing neurosurgery as indicated by the American Medical Association DoctorFinder and NPI is charted relative to year matched. Figure is available in color online only.

\section{Discussion}

Attrition impacts the neurosurgical workforce pipeline relatively more than board certification, as the latter is a voluntary process. Understanding factors impacting attrition enables addressing them.

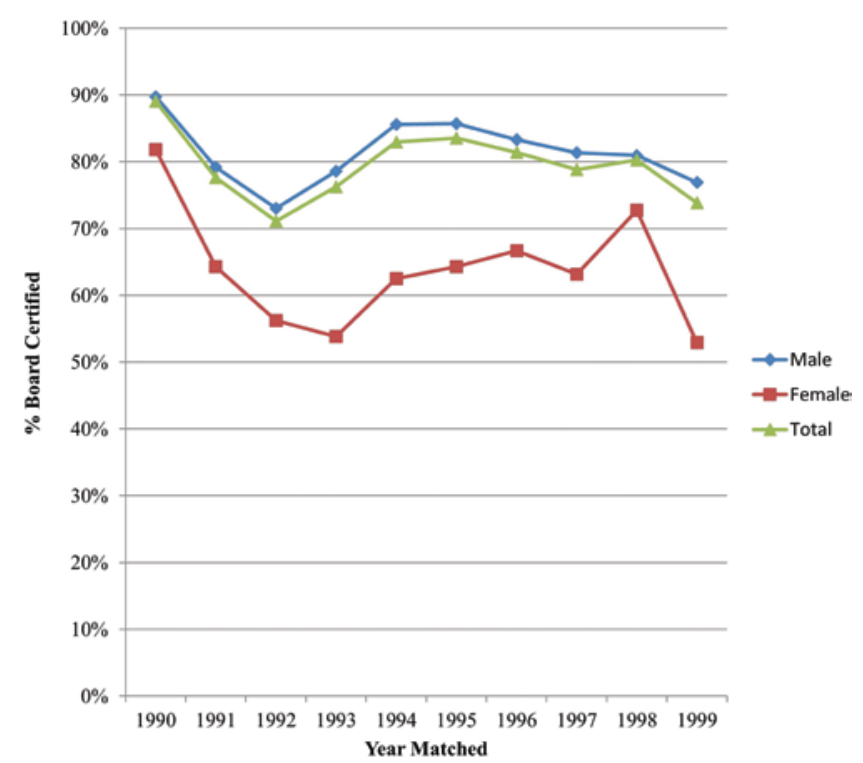

FIG. 3. The percentage of matched applicants from 1990 to 1999 who are ABNS certified in neurosurgery as indicated by the ABNS directory is charted relative to year matched. Figure is available in color online only. 


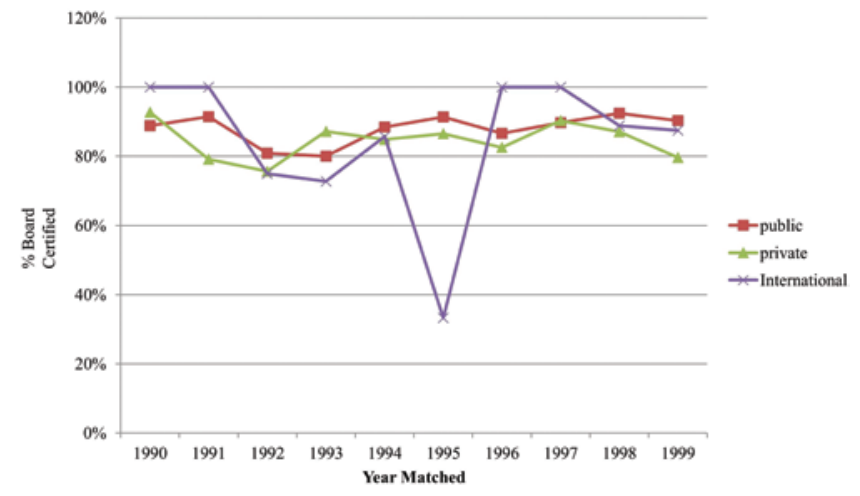

FIG. 4. The percentage of alumni achieving board certification by type of medical school attended is charted relative to year matched. Figure is available in color online only.

The residency completion rate for neurosurgery was $86.0 \%$ suggesting an attrition rate of $2 \%$ per year of training for a 7-year program. Direct comparison with other specialties is obfuscated by different methods of data collection. Surveys of ophthalmology program directors suggest an attrition rate of $1.1 \%$ per year. ${ }^{12,16}$ Similar surveys to obstetrics program directors suggested attrition of $3.74 \%$ per year. ${ }^{17}$ A 20 -year audit of the Yale general surgery program from 1986 to 2006 demonstrated a $6.7 \%$ annual attrition rate, with $39 \%$ of women and $26 \%$ of men failing to finish the program. The statistics may appear inflated because some residents left for programs with greater specialty training, such as plastic surgery. ${ }^{14}$ Post80-hour work-week attrition analysis demonstrates that $19.6 \%$ of general surgery residents leave training, with women twice as likely to leave as men. ${ }^{23}$

\section{The Impact of Medical School Ranking on Attrition}

Our data demonstrate that medical school alumni graduating from schools rated in the top 10 by US News and World Report did not have significantly different attrition from alumni of non-top 10 schools. One limitation of this analysis is that only a single measure of medical school rank was used for this study.
TABLE 2. Fates of matched applicants who were not board certified in neurosurgery

\begin{tabular}{lc}
\hline \multicolumn{1}{c}{ Career } & No. of Applicants \\
\hline Neurosurgery & 90 \\
\hline Radiology & 36 \\
\hline Anesthesiology & 21 \\
\hline Emergency medicine & 19 \\
\hline Neurology & 11 \\
\hline Internal medicine & 10 \\
\hline General surgery & 8 \\
\hline Family medicine & 7 \\
\hline Orthopedic surgery & 7 \\
\hline Pain medicine & 6 \\
\hline Dermatology & 5 \\
\hline Ophthalmology & 5 \\
\hline Pediatrics & 4 \\
\hline Psychiatry & 4 \\
\hline Radiation oncology/nuclear medicine & 4 \\
\hline Pathology & 3 \\
\hline Hematology/oncology & 2 \\
\hline Otolaryngology & 2 \\
\hline Urology & 2 \\
\hline Other specialty* & 9 \\
\hline Out of practice† & 18 \\
\hline Lost to follow-up or deceased & 7 \\
\hline Total & 280 \\
\hline
\end{tabular}

* Transplant, vascular, craniofacial/plastics, cardiology, physical medicine and rehabilitation, obstetrics and gynecology, occupational medicine, medical genetics.

† Entrepreneur or finance $(n=11)$, legal $(n=3)$, academic/research $(n=4)$.

\section{The Impact of Public Versus Private Versus International Medical School Training on Attrition}

Despite the fact that there are a greater total number of medical students enrolled at public medical schools versus private medical schools, our data demonstrate

TABLE 1. Breakdown of matched applicants by year, sex, and type of school attended

\begin{tabular}{|c|c|c|c|c|c|c|c|c|c|c|c|}
\hline \multirow[b]{2}{*}{ Variable } & \multicolumn{10}{|c|}{ No. of Applicants } & \multirow[b]{2}{*}{ Tota } \\
\hline & 1990 & 1991 & 1992 & 1993 & 1994 & 1995 & 1996 & 1997 & 1998 & 1999 & \\
\hline Men matched & 117 & 120 & 126 & 126 & 125 & 126 & 114 & 118 & 126 & 117 & 1215 \\
\hline Men ABNS certified & 105 & 95 & 92 & 99 & 107 & 108 & 95 & 96 & 102 & 90 & 989 \\
\hline Women matched & 11 & 14 & 16 & 13 & 16 & 14 & 15 & 19 & 11 & 17 & 146 \\
\hline Women ABNS certified & 9 & 9 & 9 & 7 & 10 & 9 & 10 & 12 & 8 & 9 & 92 \\
\hline Public grads matched & 54 & 59 & 68 & 50 & 61 & 70 & 60 & 68 & 66 & 62 & 618 \\
\hline Public grads ABNS certified & 46 & 51 & 50 & 36 & 53 & 61 & 49 & 58 & 55 & 49 & 508 \\
\hline Private grads matched & 69 & 72 & 70 & 78 & 73 & 67 & 63 & 62 & 62 & 64 & 680 \\
\hline Private grads ABNS certified & 63 & 50 & 49 & 62 & 58 & 55 & 50 & 46 & 48 & 43 & 524 \\
\hline Int'l grads matched & 5 & 3 & 4 & 11 & 7 & 3 & 6 & 7 & 9 & 8 & 63 \\
\hline Int'l grads ABNS certified & 5 & 3 & 2 & 8 & 6 & 1 & 6 & 4 & 7 & 7 & 49 \\
\hline Total matched & 128 & 134 & 142 & 139 & 141 & 140 & 129 & 137 & 137 & 134 & 1361 \\
\hline Total ABNS certified & 114 & 104 & 101 & 106 & 117 & 117 & 105 & 108 & 110 & 99 & 1081 \\
\hline
\end{tabular}

Grad = medical school graduate; int'l = international medical school; private = private medical school; public = public medical school . 
TABLE 3. Board certification rates by individual medical school attended

\begin{tabular}{|c|c|c|c|c|c|c|c|c|c|}
\hline Medical School & $\begin{array}{l}\text { Males Not } \\
\text { Board } \\
\text { Certified }\end{array}$ & $\begin{array}{l}\text { Total No. } \\
\text { of Males }\end{array}$ & $\begin{array}{l}\text { \% Males } \\
\text { Not Board } \\
\text { Certified }\end{array}$ & $\begin{array}{l}\text { Females } \\
\text { Not Board } \\
\text { Certified }\end{array}$ & $\begin{array}{c}\text { Total } \\
\text { No. of } \\
\text { Females }\end{array}$ & $\begin{array}{c}\% \text { Females } \\
\text { Not Board } \\
\text { Certified }\end{array}$ & $\begin{array}{c}\text { Total Not } \\
\text { Board } \\
\text { Certified }\end{array}$ & Total & $\begin{array}{c}\% \text { Total } \\
\text { Not Board } \\
\text { Certified }\end{array}$ \\
\hline University of Nebraska & 0 & 9 & $0.0 \%$ & 0 & 1 & $0.0 \%$ & 0 & 10 & $0.0 \%$ \\
\hline University of Alabama & 0 & 15 & $0.0 \%$ & 0 & 3 & $0.0 \%$ & 0 & 18 & $0.0 \%$ \\
\hline Brown University & 0 & 9 & $0.0 \%$ & 0 & 1 & $0.0 \%$ & 0 & 10 & $0.0 \%$ \\
\hline VCU Medical Center & 1 & 18 & $5.6 \%$ & 0 & 1 & $0.0 \%$ & 1 & 19 & $5.3 \%$ \\
\hline University of Cincinnati & 1 & 15 & $6.7 \%$ & 0 & 1 & $0.0 \%$ & 1 & 16 & $6.3 \%$ \\
\hline Washington University & 1 & 14 & $7.1 \%$ & 0 & 2 & $0.0 \%$ & 1 & 16 & $6.3 \%$ \\
\hline University of Maryland & 1 & 12 & $8.3 \%$ & 0 & 1 & $0.0 \%$ & 1 & 13 & $7.7 \%$ \\
\hline University of Florida & 0 & 11 & $0.0 \%$ & 1 & 1 & $100.0 \%$ & 1 & 12 & $8.3 \%$ \\
\hline UCSF & 1 & 12 & $8.3 \%$ & 0 & 0 & NA & 1 & 12 & $8.3 \%$ \\
\hline Northwestern University & 1 & 19 & $5.3 \%$ & 1 & 4 & $25.0 \%$ & 2 & 23 & $8.7 \%$ \\
\hline Vanderbilt University & 1 & 9 & $11.1 \%$ & 0 & 1 & $0.0 \%$ & 1 & 10 & $10.0 \%$ \\
\hline University of Texas at Dallas & 1 & 10 & $10.0 \%$ & 0 & 0 & NA & 1 & 10 & $10.0 \%$ \\
\hline USC & 1 & 17 & $5.9 \%$ & 1 & 1 & $100.0 \%$ & 2 & 18 & $11.1 \%$ \\
\hline University of lowa & 1 & 14 & $7.1 \%$ & 1 & 2 & $50.0 \%$ & 2 & 16 & $12.5 \%$ \\
\hline Baylor COM & 3 & 19 & $15.8 \%$ & 0 & 2 & $0.0 \%$ & 3 & 21 & $14.3 \%$ \\
\hline Indiana University & 3 & 22 & $13.6 \%$ & 1 & 4 & $25.0 \%$ & 4 & 26 & $15.4 \%$ \\
\hline Loyola-Stritch SOM & 3 & 15 & $20.0 \%$ & 0 & 4 & $0.0 \%$ & 3 & 19 & $15.8 \%$ \\
\hline Cornell University & 4 & 24 & $16.7 \%$ & 0 & 1 & $0.0 \%$ & 4 & 25 & $16.0 \%$ \\
\hline SUNY-Syracuse & 0 & 8 & $0.0 \%$ & 2 & 4 & $50.0 \%$ & 2 & 12 & $16.7 \%$ \\
\hline University of Oklahoma & 1 & 10 & $10.0 \%$ & 1 & 2 & $50.0 \%$ & 2 & 12 & $16.7 \%$ \\
\hline St. Louis University & 1 & 11 & $9.1 \%$ & 1 & 1 & $100.0 \%$ & 2 & 12 & $16.7 \%$ \\
\hline University of Chicago & 3 & 19 & $15.8 \%$ & 1 & 4 & $25.0 \%$ & 4 & 23 & $17.4 \%$ \\
\hline New York University & 5 & 26 & $19.2 \%$ & 0 & 2 & $0.0 \%$ & 5 & 28 & $17.9 \%$ \\
\hline Rush Medical College & 1 & 8 & $12.5 \%$ & 1 & 3 & $33.3 \%$ & 2 & 11 & $18.2 \%$ \\
\hline Jefferson Medical College & 2 & 10 & $20.0 \%$ & 0 & 1 & $0.0 \%$ & 2 & 11 & $18.2 \%$ \\
\hline University of Texas at Galveston & 2 & 11 & $18.1 \%$ & 0 & 0 & NA & 2 & 11 & $18.2 \%$ \\
\hline UCLA & 3 & 19 & $15.8 \%$ & 1 & 1 & $100.0 \%$ & 4 & 20 & $20.0 \%$ \\
\hline University of Colorado & 2 & 9 & $22.2 \%$ & 0 & 1 & $0.0 \%$ & 2 & 10 & $20.0 \%$ \\
\hline Columbia University & 8 & 42 & $19.0 \%$ & 2 & 7 & $28.6 \%$ & 10 & 49 & $20.4 \%$ \\
\hline Albany Medical College & 3 & 16 & $18.8 \%$ & 1 & 3 & $33.3 \%$ & 4 & 19 & $21.1 \%$ \\
\hline University of Texas at San Antonio & 3 & 13 & $23.1 \%$ & 0 & 1 & $0.0 \%$ & 3 & 14 & $21.4 \%$ \\
\hline University of Michigan & 5 & 19 & $26.3 \%$ & 0 & 4 & $0.0 \%$ & 5 & 23 & $21.7 \%$ \\
\hline University of Virginia & 5 & 22 & $22.7 \%$ & 0 & 1 & $0.0 \%$ & 5 & 23 & $21.7 \%$ \\
\hline Johns Hopkins University & 8 & 42 & $19.0 \%$ & 3 & 7 & $42.9 \%$ & 11 & 49 & $22.4 \%$ \\
\hline Harvard University & 7 & 39 & $17.9 \%$ & 3 & 5 & $60.0 \%$ & 10 & 44 & $22.7 \%$ \\
\hline Yale University & 6 & 30 & $20.0 \%$ & 2 & 4 & $50.0 \%$ & 8 & 34 & $23.5 \%$ \\
\hline Tulane University & 4 & 16 & $25.0 \%$ & 1 & 4 & $25.0 \%$ & 5 & 20 & $25.0 \%$ \\
\hline Temple University & 3 & 17 & $17.6 \%$ & 2 & 3 & $66.7 \%$ & 5 & 20 & $25.0 \%$ \\
\hline University of Pennsylvania & 3 & 16 & $18.8 \%$ & 2 & 4 & $50.0 \%$ & 5 & 20 & $25.0 \%$ \\
\hline Stanford University & 3 & 11 & $27.3 \%$ & 1 & 4 & $25.0 \%$ & 4 & 15 & $26.7 \%$ \\
\hline Wake Forest University SOM & 4 & 13 & $30.8 \%$ & 0 & 1 & $0.0 \%$ & 4 & 14 & $28.6 \%$ \\
\hline Case Western Reserve & 2 & 9 & $22.2 \%$ & 1 & 1 & $100.0 \%$ & 3 & 10 & $30.0 \%$ \\
\hline University of Texas-Houston & 3 & 10 & $30.0 \%$ & 0 & 0 & NA & 3 & 10 & $30.0 \%$ \\
\hline Georgetown University & 7 & 24 & $29.2 \%$ & 1 & 2 & $50.0 \%$ & 8 & 26 & $30.8 \%$ \\
\hline Medical College of Georgia & 3 & 13 & $23.1 \%$ & 2 & 3 & $66.7 \%$ & 5 & 16 & $31.3 \%$ \\
\hline SUNY-Brooklyn & 6 & 18 & $33.3 \%$ & 0 & 1 & $0.0 \%$ & 6 & 19 & $31.5 \%$ \\
\hline Ohio State University & 5 & 15 & $33.3 \%$ & 0 & 0 & NA & 5 & 15 & $33.3 \%$ \\
\hline
\end{tabular}


TABLE 3. Board certification rates by individual medical school attended (continued)

\begin{tabular}{|c|c|c|c|c|c|c|c|c|c|}
\hline Medical School & $\begin{array}{l}\text { Males Not } \\
\text { Board } \\
\text { Certified }\end{array}$ & $\begin{array}{l}\text { Total No. } \\
\text { of Males }\end{array}$ & $\begin{array}{l}\% \text { Males } \\
\text { Not Board } \\
\text { Certified }\end{array}$ & $\begin{array}{c}\text { Females } \\
\text { Not Board } \\
\text { Certified }\end{array}$ & $\begin{array}{c}\text { Total } \\
\text { No. of } \\
\text { Females }\end{array}$ & $\begin{array}{c}\% \text { Females } \\
\text { Not Board } \\
\text { Certified }\end{array}$ & $\begin{array}{c}\text { Total Not } \\
\text { Board } \\
\text { Certified }\end{array}$ & Total & $\begin{array}{c}\% \text { Total } \\
\text { Not Board } \\
\text { Certified }\end{array}$ \\
\hline Duke University & 5 & 14 & $35.7 \%$ & 0 & 0 & NA & 5 & 14 & $35.7 \%$ \\
\hline University of Kansas & 4 & 11 & $36.4 \%$ & 0 & 0 & NA & 4 & 11 & $36.4 \%$ \\
\hline University of Louisville & 4 & 11 & $36.4 \%$ & 0 & 0 & NA & 4 & 11 & $36.4 \%$ \\
\hline Albert Einstein COM & 4 & 8 & $50.0 \%$ & 1 & 2 & $50.0 \%$ & 5 & 10 & $50.0 \%$ \\
\hline George Washington University & 6 & 14 & $42.9 \%$ & 4 & 4 & $100.0 \%$ & 10 & 18 & $55.6 \%$ \\
\hline
\end{tabular}

COM = College of Medicine; NA = not applicable; SOM = School of Medicine; SUNY = State University of New York; UCLA = University of California, Los Angeles; UCSF = University of California, San Francisco; USC = University of Southern California; VCU = Virginia Commonwealth University.

that more physicians matched into neurosurgery graduate from private schools $(n=680)$ than public schools $(n$ $=618$ ). Public medical school alumni have significantly lower attrition than private school alumni. Four potential hypotheses are among many that could contribute to this phenomenon: 1) Private school graduates may simply be more willing to change their career trajectory than those coming from public schools. 2) It may be more difficult for public school alumni to match into neurosurgery; those who do match may be thus less likely to leave. 3) Private school alumni may have greater socioeconomic resources than public school alumni and thus may be more willing to look at other career options after matching into neurosurgery. 4) Public schools may provide better preparation for residency.

\section{The Number of Women Entering Neurosurgery Has Increased but Is Not Commensurate With the Pipeline}

In 1986, 11,551 women applied to medical school (35\% of the total number of applicants); 5520 enrolled (34\%) and 4957 graduated (31\% of total). ${ }^{4}$ Eleven women matched into neurosurgery residency in 1990 (8.6\% of 128 ; Table $1)$, and 9 became board certified (7.9\%).

Nearly 10 years later, in 1995, 19,776 women applied to medical school (43\% of the total number of total applicants); 6941 enrolled (43\%) and 6501 graduated (41\% of total). ${ }^{4}$ Seventeen of those women matched into neurosurgery in 1999 (12.7\% of total; Table 1), and 9 became board certified by November 2013 (9.1\%). Thus the odds of a female medical school applicant becoming a board-certified neurosurgeon fell from 1:1283 in 1986 to 1:2197 in 1995.

Between 1990 and 1999, 21 of 92 neurosurgery residency programs matched no female applicants. More than one-third of neurosurgery residency programs (33 of 92) did not have a single female matched applicant who had become board certified by November 2013 (Table 4).

Since 2004, at least $47 \%$ of medical school graduates are women. ${ }^{4}$ As the percentage of women graduating from medical school approaches parity with men, ${ }^{4}$ there has been a commensurate increase in women in general surgery, with women making up 30\% of the general surgery resident positions ${ }^{8}$ in 2007 and $37.4 \%$ in $2011 .{ }^{1}$ Neurosurgery and orthopedic surgery have not kept pace with the pipeline increases in female medical school graduates. ${ }^{7}$ In $2011,13.6 \%$ of orthopedic surgery residents were female. ${ }^{1}$ As per the ABNS, during the 2011-2012 academic year, $15.5 \%$ of neurosurgery residents were female. ${ }^{15}$

\section{Women Have Substantially Higher Attrition During and After Neurosurgery Residency Training}

Our data demonstrate that nearly 4 in 10 women who began neurosurgical residency between 1990 and 1999 did not become board certified, and that women were twice as likely as men not to become board certified (Table 1, Fig. 1).

Few studies have evaluated the reasons for female attrition in neurosurgery; ${ }^{5,22}$ however, the subject has been investigated among general surgeons. Reasons for leaving general surgery residency have been evaluated in single studies on program attrition predating the 80-hour work week and found that women were more likely to leave for lifestyle reasons. ${ }^{6,10}$ A survey of 4402 general surgery residents demonstrated that married parents reported both greater satisfaction and work-life conflict and female residents looked forward to work less than male residents did. ${ }^{19}$ Female surgeons are noted to have greater workhome conflicts than male surgeons. ${ }^{11}$

Surveys of collegiality and socialization between residents and attending physicians have demonstrated that residents who are male, parents, and older are more likely to socialize with attending physicians ${ }^{18}$ Female residents are less likely to feel that they can approach faculty when having difficulty, and residents who were unable to approach faculty were 5-fold more dissatisfied with their training. ${ }^{18}$ The fear of impropriety may impede mentoring relationships and collegiality between female residents and predominantly male faculty and peers.

Interaction with colleagues and cooperative working relationships have been found to be statistically significantly associated with job satisfaction in a survey of practicing academic physicians. ${ }^{13}$ Structured mentoring also improves faculty retention. ${ }^{21}$

Surveys of women in academic medicine have found that minority women are most likely to leave, ${ }^{2}$ and the three most commonly associated reasons are inequity in professional advancement, lower salary than peers, and problems with departmental chairs and leadership. ${ }^{9}$ Women in academic medicine, and minority women in particular, start with lower pay and fewer research resources. ${ }^{2,24}$ Female general surgeons are promoted less rapidly and face both overt and covert discrimination. ${ }^{24}$

There are very few women in leadership roles in neurosurgery. A review of 2010 data maintained by the AANS suggested that there were 5 female tenured full professors in the US of 213 full neurosurgery professors (2.3\%), ex- 
TABLE 4. Board certification rates by individual residency program at which applicant matched

\begin{tabular}{|c|c|c|c|c|c|c|c|c|c|c|}
\hline \multirow[b]{2}{*}{ Program Name } & \multirow[b]{2}{*}{$\begin{array}{c}\text { Total Attrition } \\
\text { Rate }\end{array}$} & \multicolumn{3}{|c|}{ Male Residents } & \multicolumn{3}{|c|}{ Female Residents } & \multicolumn{3}{|c|}{ Total Residents } \\
\hline & & No. & $\begin{array}{l}\text { No. Board } \\
\text { Certified }\end{array}$ & $\begin{array}{l}\% \text { Board } \\
\text { Certified }\end{array}$ & No. & $\begin{array}{l}\text { No. Board } \\
\text { Certified }\end{array}$ & $\begin{array}{l}\% \text { Board } \\
\text { Certified }\end{array}$ & No. & $\begin{array}{l}\text { No. Board } \\
\text { Certified }\end{array}$ & $\begin{array}{l}\% \text { Board } \\
\text { Certified }\end{array}$ \\
\hline Columbia University & $0 \%$ & 20 & 20 & $100 \%$ & 1 & 1 & $100 \%$ & 21 & 21 & $100 \%$ \\
\hline University of South Florida & $0 \%$ & 6 & 6 & $100 \%$ & 1 & 1 & $100 \%$ & 7 & 7 & $100 \%$ \\
\hline UMDNJ, Newark & $0 \%$ & 7 & 7 & $100 \%$ & 1 & 1 & $100 \%$ & 8 & 8 & $100 \%$ \\
\hline UC, Irvine & $0 \%$ & 6 & 6 & $100 \%$ & 0 & 0 & NA & 6 & 6 & $100 \%$ \\
\hline University of Kentucky & $0 \%$ & 14 & 14 & $100 \%$ & 0 & 0 & NA & 14 & 14 & $100 \%$ \\
\hline Baylor COM & $3 \%$ & 27 & 26 & $96 \%$ & 2 & 2 & $100 \%$ & 29 & 28 & $97 \%$ \\
\hline Johns Hopkins University & $4 \%$ & 24 & 23 & $95 \%$ & 1 & 1 & $100 \%$ & 25 & 24 & $96 \%$ \\
\hline Barrow Neurological Institute, Phoenix & $5 \%$ & 21 & 20 & $95 \%$ & 1 & 1 & $100 \%$ & 22 & 21 & $95 \%$ \\
\hline Vanderbilt University & $5 \%$ & 19 & 18 & $95 \%$ & 1 & 1 & $100 \%$ & 20 & 19 & $95 \%$ \\
\hline University of Illinois & $6 \%$ & 13 & 12 & $92 \%$ & 3 & 3 & $100 \%$ & 16 & 15 & $94 \%$ \\
\hline University of Virginia & $10 \%$ & 21 & 19 & $90 \%$ & 0 & 0 & NA & 21 & 19 & $90 \%$ \\
\hline University of Colorado & $10 \%$ & 6 & 6 & $100 \%$ & 4 & 3 & $75 \%$ & 10 & 9 & $90 \%$ \\
\hline LSU, New Orleans & $10 \%$ & 10 & 9 & $90 \%$ & 0 & 0 & NA & 10 & 9 & $90 \%$ \\
\hline Stanford University & $10 \%$ & 8 & 7 & $88 \%$ & 2 & 2 & $100 \%$ & 10 & 9 & $90 \%$ \\
\hline Tulane University, New Orleans & $10 \%$ & 6 & 5 & $83 \%$ & 4 & 4 & $100 \%$ & 10 & 9 & $90 \%$ \\
\hline University of lowa & $11 \%$ & 17 & 16 & $94 \%$ & 2 & 1 & $50 \%$ & 19 & 17 & $89 \%$ \\
\hline Washington University St. Louis & $11 \%$ & 16 & 15 & $94 \%$ & 2 & 1 & $50 \%$ & 18 & 16 & $89 \%$ \\
\hline University of Arkansas & $11 \%$ & 9 & 8 & $89 \%$ & 0 & 0 & NA & 9 & 8 & $89 \%$ \\
\hline University of Pittsburgh & $12 \%$ & 24 & 22 & $92 \%$ & 2 & 1 & $50 \%$ & 26 & 23 & $88 \%$ \\
\hline Indiana University & $13 \%$ & 13 & 11 & $85 \%$ & 3 & 3 & $100 \%$ & 16 & 14 & $88 \%$ \\
\hline St. Louis University & $13 \%$ & 7 & 6 & $86 \%$ & 1 & 1 & $100 \%$ & 8 & 7 & $88 \%$ \\
\hline University of Connecticut & $13 \%$ & 8 & 7 & $88 \%$ & 0 & 0 & NA & 8 & 7 & $88 \%$ \\
\hline Mount Sinai, New York & $14 \%$ & 19 & 17 & $89 \%$ & 2 & 1 & $50 \%$ & 21 & 18 & $86 \%$ \\
\hline UCSF & $14 \%$ & 16 & 15 & $94 \%$ & 5 & 3 & $60 \%$ & 21 & 18 & $86 \%$ \\
\hline Allegheny General Hospital, Pittsburgh & $14 \%$ & 7 & 6 & $86 \%$ & 0 & 0 & NA & 7 & 6 & $86 \%$ \\
\hline University of Nebraska & $14 \%$ & 6 & 5 & $83 \%$ & 1 & 1 & $100 \%$ & 7 & 6 & $86 \%$ \\
\hline University of Minnesota & $14 \%$ & 21 & 18 & $86 \%$ & 0 & 0 & NA & 21 & 18 & $86 \%$ \\
\hline Loyola University & $15 \%$ & 13 & 11 & $85 \%$ & 0 & 0 & NA & 13 & 11 & $85 \%$ \\
\hline New York University & $15 \%$ & 18 & 16 & $89 \%$ & 2 & 1 & $50 \%$ & 20 & 17 & $85 \%$ \\
\hline Mayo Clinic & $16 \%$ & 18 & 16 & $89 \%$ & 1 & 0 & $0 \%$ & 19 & 16 & $84 \%$ \\
\hline Northwestern University & $16 \%$ & 16 & 13 & $81 \%$ & 3 & 3 & $100 \%$ & 19 & 16 & $84 \%$ \\
\hline University of Cincinnati & $16 \%$ & 19 & 16 & $84 \%$ & 0 & 0 & NA & 19 & 16 & $84 \%$ \\
\hline University of Pennsylvania & $16 \%$ & 17 & 14 & $82 \%$ & 2 & 2 & $100 \%$ & 19 & 16 & $84 \%$ \\
\hline University of Tennessee at Memphis & $20 \%$ & 22 & 18 & $82 \%$ & 3 & 3 & $100 \%$ & 25 & 21 & $84 \%$ \\
\hline VCU Medical Center & $17 \%$ & 16 & 14 & $88 \%$ & 2 & 1 & $50 \%$ & 18 & 15 & $83 \%$ \\
\hline University of Oklahoma & $17 \%$ & 12 & 10 & $83 \%$ & 0 & 0 & NA & 12 & 10 & $83 \%$ \\
\hline Oregon Health \& Science University & $18 \%$ & 10 & 9 & $90 \%$ & 1 & 0 & $0 \%$ & 11 & 9 & $82 \%$ \\
\hline University of Washington & $18 \%$ & 20 & 17 & $85 \%$ & 2 & 1 & $50 \%$ & 22 & 18 & $82 \%$ \\
\hline University of Texas at Dallas/Southwest & $18 \%$ & 35 & 28 & $80 \%$ & 3 & 3 & $100 \%$ & 38 & 31 & $82 \%$ \\
\hline USC/Los Angeles City Hospital & $19 \%$ & 20 & 17 & $85 \%$ & 1 & 0 & $0 \%$ & 21 & 17 & $81 \%$ \\
\hline Brown University & $20 \%$ & 8 & 7 & $88 \%$ & 2 & 1 & $50 \%$ & 10 & 8 & $80 \%$ \\
\hline Georgetown University & $20 \%$ & 8 & 7 & $88 \%$ & 2 & 1 & $50 \%$ & 10 & 8 & $80 \%$ \\
\hline New York Medical College & $20 \%$ & 8 & 7 & $88 \%$ & 2 & 1 & $50 \%$ & 10 & 8 & $80 \%$ \\
\hline Ohio State University & $20 \%$ & 16 & 14 & $88 \%$ & 4 & 2 & $50 \%$ & 20 & 16 & $80 \%$ \\
\hline Hahnemann Medical College, Philadelphia & $20 \%$ & 5 & 4 & $80 \%$ & 0 & 0 & NA & 5 & 4 & $80 \%$ \\
\hline Medical University of South Carolina & $20 \%$ & 10 & 8 & $80 \%$ & 0 & 0 & NA & 10 & 8 & $80 \%$ \\
\hline Rush/Presbyterian/St. Luke's & $20 \%$ & 8 & 6 & $75 \%$ & 2 & 2 & $100 \%$ & 10 & 8 & $80 \%$ \\
\hline
\end{tabular}


TABLE 4. Board certification rates by individual residency program at which applicant matched (continued)

\begin{tabular}{|c|c|c|c|c|c|c|c|c|c|c|}
\hline \multirow[b]{2}{*}{ Program Name } & \multirow[b]{2}{*}{$\begin{array}{l}\text { Total Attrition } \\
\text { Rate }\end{array}$} & \multicolumn{3}{|c|}{ Male Residents } & \multicolumn{3}{|c|}{ Female Residents } & \multicolumn{3}{|c|}{ Total Residents } \\
\hline & & No. & $\begin{array}{c}\text { No. Board } \\
\text { Certified }\end{array}$ & $\begin{array}{l}\% \text { Board } \\
\text { Certified }\end{array}$ & No. & $\begin{array}{l}\text { No. Board } \\
\text { Certified }\end{array}$ & $\begin{array}{l}\% \text { Board } \\
\text { Certified }\end{array}$ & No. & $\begin{array}{c}\text { No. Board } \\
\text { Certified }\end{array}$ & $\begin{array}{l}\% \text { Board } \\
\text { Certified }\end{array}$ \\
\hline Tufts University & $20 \%$ & 8 & 6 & $75 \%$ & 2 & 2 & $100 \%$ & 10 & 8 & $80 \%$ \\
\hline UCSD & $20 \%$ & 10 & 8 & $80 \%$ & 0 & 0 & NA & 10 & 8 & $80 \%$ \\
\hline UCLA & $20 \%$ & 19 & 15 & $79 \%$ & 1 & 1 & $100 \%$ & 20 & 16 & $80 \%$ \\
\hline University of Maryland & $20 \%$ & 13 & 10 & $77 \%$ & 2 & 2 & $100 \%$ & 15 & 12 & $80 \%$ \\
\hline University of Mississippi & $20 \%$ & 10 & 8 & $80 \%$ & 0 & 0 & NA & 10 & 8 & $80 \%$ \\
\hline Emory University & $21 \%$ & 17 & 14 & $82 \%$ & 2 & 1 & $50 \%$ & 19 & 15 & $79 \%$ \\
\hline George Washington University & $21 \%$ & 17 & 14 & $82 \%$ & 2 & 1 & $50 \%$ & 19 & 15 & $79 \%$ \\
\hline University of Michigan & $21 \%$ & 16 & 13 & $81 \%$ & 3 & 2 & $67 \%$ & 19 & 15 & $79 \%$ \\
\hline Harvard University & $22 \%$ & 35 & 28 & $80 \%$ & 2 & 1 & $50 \%$ & 37 & 29 & $78 \%$ \\
\hline Medical College of Wisconsin & $22 \%$ & 7 & 6 & $86 \%$ & 2 & 1 & $50 \%$ & 9 & 7 & $78 \%$ \\
\hline University of Louisville & $22 \%$ & 9 & 7 & $78 \%$ & 0 & 0 & NA & 9 & 7 & $78 \%$ \\
\hline University of Missouri, Columbia & $22 \%$ & 8 & 7 & $88 \%$ & 1 & 0 & $0 \%$ & 9 & 7 & $78 \%$ \\
\hline Bowman Gray, North Carolina & $22 \%$ & 9 & 7 & $78 \%$ & 0 & 0 & NA & 9 & 7 & $78 \%$ \\
\hline University of Florida, Gainesville & $23 \%$ & 21 & 17 & $81 \%$ & 1 & 0 & $0 \%$ & 22 & 17 & $77 \%$ \\
\hline Cleveland Clinic & $24 \%$ & 19 & 15 & $79 \%$ & 2 & 1 & $50 \%$ & 21 & 16 & $76 \%$ \\
\hline University of New Mexico & $25 \%$ & 3 & 3 & $100 \%$ & 1 & 0 & $0 \%$ & 4 & 3 & $75 \%$ \\
\hline University of Rochester & $27 \%$ & 11 & 8 & $73 \%$ & 0 & 0 & NA & 11 & 8 & $73 \%$ \\
\hline Cornell/New York Hospital & $29 \%$ & 13 & 9 & $69 \%$ & 1 & 1 & $100 \%$ & 14 & 10 & $71 \%$ \\
\hline Loma Linda University & $29 \%$ & 7 & 5 & $71 \%$ & 0 & 0 & NA & 7 & 5 & $71 \%$ \\
\hline University of Alabama at Birmingham & $29 \%$ & 12 & 8 & $67 \%$ & 2 & 2 & $100 \%$ & 14 & 10 & $71 \%$ \\
\hline University of Utah & $29 \%$ & 19 & 13 & $68 \%$ & 2 & 2 & $100 \%$ & 21 & 15 & $71 \%$ \\
\hline Albany Medical College & $30 \%$ & 9 & 7 & $78 \%$ & 1 & 0 & $0 \%$ & 10 & 7 & $70 \%$ \\
\hline Medical College of Georgia & $30 \%$ & 7 & 6 & $86 \%$ & 3 & 1 & $33 \%$ & 10 & 7 & $70 \%$ \\
\hline UC, Davis & $30 \%$ & 6 & 5 & $83 \%$ & 4 & 2 & $50 \%$ & 10 & 7 & $70 \%$ \\
\hline University of Vermont & $30 \%$ & 9 & 6 & $67 \%$ & 1 & 1 & $100 \%$ & 10 & 7 & $70 \%$ \\
\hline Case Western Reserve & $30 \%$ & 17 & 13 & $76 \%$ & 6 & 3 & $50 \%$ & 23 & 16 & $70 \%$ \\
\hline Albert Einstein COM & $31 \%$ & 15 & 11 & $73 \%$ & 1 & 0 & $0 \%$ & 16 & 11 & $69 \%$ \\
\hline University of Miami & $32 \%$ & 17 & 12 & $71 \%$ & 2 & 1 & $50 \%$ & 19 & 13 & $68 \%$ \\
\hline Henry Ford Hospital & $33 \%$ & 18 & 12 & $67 \%$ & 3 & 2 & $67 \%$ & 21 & 14 & $67 \%$ \\
\hline Temple University, Philadelphia & $33 \%$ & 7 & 5 & $71 \%$ & 2 & 1 & $50 \%$ & 9 & 6 & $67 \%$ \\
\hline Eastern Virginia Medical School & $33 \%$ & 2 & 1 & $50 \%$ & 1 & 1 & $100 \%$ & 3 & 2 & $67 \%$ \\
\hline University of Chicago & $33 \%$ & 9 & 6 & $67 \%$ & 0 & 0 & NA & 9 & 6 & $67 \%$ \\
\hline University of Wisconsin & $33 \%$ & 8 & 5 & $63 \%$ & 1 & 1 & $100 \%$ & 9 & 6 & $67 \%$ \\
\hline Wayne State University & $33 \%$ & 8 & 5 & $63 \%$ & 1 & 1 & $100 \%$ & 9 & 6 & $67 \%$ \\
\hline Duke University & $35 \%$ & 18 & 12 & $67 \%$ & 2 & 1 & $50 \%$ & 20 & 13 & $65 \%$ \\
\hline Dartmouth-Hitchcock & $36 \%$ & 10 & 7 & $70 \%$ & 1 & 0 & $0 \%$ & 11 & 7 & $64 \%$ \\
\hline SUNY & $38 \%$ & 32 & 21 & $66 \%$ & 7 & 3 & $42 \%$ & 39 & 24 & $62 \%$ \\
\hline University of Puerto Rico & $40 \%$ & 9 & 6 & $67 \%$ & 1 & 0 & $0 \%$ & 10 & 6 & $60 \%$ \\
\hline University of North Carolina, Chapel Hill & $40 \%$ & 9 & 6 & $67 \%$ & 1 & 0 & $0 \%$ & 10 & 6 & $60 \%$ \\
\hline Yale University & $40 \%$ & 7 & 5 & $71 \%$ & 3 & 1 & $33 \%$ & 10 & 6 & $60 \%$ \\
\hline Jefferson University, Philadelphia & $40 \%$ & 14 & 8 & $57 \%$ & 1 & 1 & $100 \%$ & 15 & 9 & $60 \%$ \\
\hline University of Kansas & $40 \%$ & 10 & 6 & $60 \%$ & 0 & 0 & NA & 10 & 6 & $60 \%$ \\
\hline West Virginia University & $50 \%$ & 8 & 4 & $50 \%$ & 2 & 1 & $50 \%$ & 10 & 5 & $50 \%$ \\
\hline Pennsylvania State University & $60 \%$ & 4 & 2 & $50 \%$ & 1 & 0 & $0 \%$ & 5 & 2 & $40 \%$ \\
\hline University of Massachusetts & $80 \%$ & 4 & 0 & $0 \%$ & 1 & 1 & $100 \%$ & 5 & 1 & $20 \%$ \\
\hline
\end{tabular}

LSU = Louisiana State University; UC = University of California; UCSD = University of California, San Diego; UMDNJ = University of Medicine and Dentistry of New Jersey. 
cluding 39 service chiefs and 65 department chairs with unknown academic rank (AAMC data, obtained through institutional connection). There is currently one female department chair in neurosurgery. Although neurosurgery has a higher percentage of female practitioners (approximately $6 \%$ ) than orthopedic surgery $(4.8 \%)$, the number of female faculty members and full professors is lower. In 2012, 15\% of orthopedic surgery faculty were women, with $7 \%$ serving as full professors. ${ }^{3}$

One might speculate that the relative parity of women in college and medical school and availability of female faculty mentors in other fields creates a particularly jarring experience for women who are entering neurosurgery and are abruptly facing a relative paucity of female peers, mentors, and role models. Such a phenomenon is exacerbated the higher a woman rises in the field as more and more women drop out, and she is left with no female colleagues or mentors.

\section{General Limitations of the Data and Their Applicability}

The data collected represent only those individuals who entered neurosurgery through the match and thus exclude physicians who acquired positions postmatch or obtained them through attrition of other physicians or program openings and expansions.

We assume that individuals who have practiced neurosurgery after residency as confirmed by the American Medical Association DoctorFinder and NPI have completed residency and are still practicing neurosurgery. The search algorithm in Fig. 1 suggests that once an individual is either found to be practicing neurosurgery or has completed residency, he or she is still practicing. This is not necessarily a valid assumption. Thus, it is possible that our study overestimates the number of neurosurgeons who have completed residency and/or are still practicing neurosurgery.

The accuracy of our study is limited to its recordable outcome measures. Board certification does not mean that someone is practicing neurosurgery, nor does lack of it mean that they are not. This is a limitation of the methodology that could be overcome by contacting individual programs and residents for a more rigorous study.

Due to the length of neurosurgical training, which we found to be longer than 12 years from match to board certification, the findings of this study are not necessarily applicable to individuals presently matching in neurosurgery. Residents who entered neurosurgical residency during the first 7 years of the study period completed their residencies prior to the introduction of the 80-hour work week. Those who entered residency during the last 3 years of the study period were senior enough in their training that they were not necessarily impacted by the 80-hour work week. Current neurosurgical residents have work-hour limitations that substantially alter workload, the nature of training, lifestyle, and other issues that impact attrition. Data regarding attrition linked to particular medical schools and residency training programs are particularly likely to have changed since most programs have changed leadership and faculty.

This study demonstrates that $19 \%$ of men and $37 \%$ of women who matched into neurosurgery over one decade did not become board-certified neurosurgeons, but it does not assess causality for attrition. Data regarding the specifics as to why these individuals did not become board certified and at what point in their training they came off track would enable better understanding of the discrepant attrition described in this study.

\section{Conclusions}

Private medical school alumni and women were less likely to become board certified than public medical school alumni and men. The percentage of women in neurosurgery has remained relatively constant for a decade due in part to a higher attrition rate for female surgeons.

\section{Acknowledgments}

We thank SF Match, the American Board of Neurological Surgery, the American Association of Neurological Surgeons, and the Ruth Jackson Orthopedic Society for access to their databases.

\section{References}

1. Although a male-dominated field, more women are pursuing an orthopedic career. Orthopedics Today. October, 2103 (http://www.healio.com/orthopedics/business-of-orthopedics /news/print/orthopedics-today/\%7B8e78161e-f87a-484fb61a-eb71d43ef2a6\%7D/although-a-male-dominated-fieldmore-women-are-pursuing-an-orthopedic-career) [Accessed October 13, 2014]

2. Ash AS, Carr PL, Goldstein R, Friedman RH: Compensation and advancement of women in academic medicine: is there equity? Ann Intern Med 141:205-212, 2004

3. Association of American Medical Colleges: Table 1: Medical students, selected years, 1965-2012. AAMC. (https://www. aamc.org/download/305282/data/2012_table1.pdf) [Accessed October 11, 2014]

4. Association of American Medical Colleges: Table 3: Distribution of full-time faculty by department, rank, and gender, 2012. AAMC. (https://www.aamc.org/download/305522/ data/2012_table3.pdf) [Accessed October 11, 2014]

5. Benzil DL, Abosch A, Germano I, Gilmer H, Maraire JN, Muraszko K, et al: The future of neurosurgery: a white paper on the recruitment and retention of women in neurosurgery. $\mathbf{J}$ Neurosurg 109:378-386, 2008

6. Bergen PC, Turnage RH, Carrico CJ: Gender-related attrition in a general surgery training program. J Surg Res 77:59-62, 1998

7. Blakemore LC, Hall JM, Biermann JS: Women in surgical residency training programs. J Bone Joint Surg Am 85A:2477-2480, 2003

8. Borman KR: Gender issues in surgical training: from minority to mainstream. Am Surg 73:161-165, 2007

9. Cropsey KL, Masho SW, Shiang R, Sikka V, Kornstein SG, Hampton CL: Why do faculty leave? Reasons for attrition of women and minority faculty from a medical school: four-year results. J Womens Health (Larchmt) 17:1111-1118, 2008

10. Dodson TF, Webb AL: Why do residents leave general surgery? The hidden problem in today's programs. Curr Surg 62:128-131, 2005

11. Dyrbye LN, Freischlag J, Kaups KL, Oreskovich MR, Satele DV, Hanks JB, et al: Work-home conflicts have a substantial impact on career decisions that affect the adequacy of the surgical workforce. Arch Surg 147:933-939, 2012

12. Hatton MP, Loewenstein J: Attrition from ophthalmology residency programs. Am J Ophthalmol 138:863-864, 2004

13. Janus K, Amelung VE, Baker LC, Gaitanides M, Schwartz FW, Rundall TG: Job satisfaction and motivation among phy- 
sicians in academic medical centers: insights from a crossnational study. J Health Polit Policy Law 33:1133-1167, 2008

14. Longo WE, Seashore J, Duffy A, Udelsman R: Attrition of categoric general surgery residents: results of a 20 -year audit. Am J Surg 197:774-780, 2009

15. Meyer FB: ABNS Newsletter, Number 30, 2012, p 4. ABNS. (http://www.abns.org/pdfs/newsletter_info_30.pdf) [Accessed October 11, 2014]

16. Najjar DM: Attrition from ophthalmology residency programs. Am J Ophthalmol 139:948, 2005 (Letter)

17. Seltzer VL, Messer RH, Nehra RD: Resident attrition in obstetrics and gynecology. Am J Obstet Gynecol 166:13151317, 1992

18. Sullivan MC, Bucholz EM, Yeo H, Roman SA, Bell RH, Sosa JA: "Join the club": effect of resident and attending social interactions on overall satisfaction among 4390 general surgery residents. Arch Surg 147:408-414, 2012

19. Sullivan MC, Yeo H, Roman SA, Bell RH Jr, Sosa JA: Striving for work-life balance: effect of marriage and children on the experience of 4402 US general surgery residents. Ann Surg 257:571-576, 2013

20. van Zanten M, Boulet JR, McKinley D, Whelan GP: Attrition rates of residents in postgraduate training programs. Teach Learn Med 14:175-177, 2002

21. Wingard DL, Garman KA, Reznik V: Facilitating faculty success: outcomes and cost benefit of the UCSD National Center of Leadership in Academic Medicine. Acad Med 79 (10 Suppl):S9-S11, 2004

22. Woodrow SI, Gilmer-Hill H, Rutka JT: The neurosurgical workforce in North America: a critical review of gender issues. Neurosurgery 59:749-758, 2006
23. Yeo H, Bucholz E, Sosa JA, Curry L, Lewis FR Jr, Jones AT, et al: A national study of attrition in general surgery training: which residents leave and where do they go? Ann Surg 252:529-536, 2010

24. Zhuge Y, Kaufman J, Simeone DM, Chen H, Velazquez OC: Is there still a glass ceiling for women in academic surgery? Ann Surg 253:637-643, 2011

\section{Author Contributions}

Conception and design: Samadani. Acquisition of data: Lynch, Puthenveettil, Reyes, Jureller, Grady, Fouke. Analysis and interpretation of data: Samadani, Lynch, Nieto, Puthenveettil, Reyes, Jureller, Ganju, Fouke. Drafting the article: Samadani, Nieto, Reyes, Jureller, Huang, Harris, Ganju, Germano, Pilitsis, Pannullo, Benzil, Abosch, Fouke. Critically revising the article: Samadani, Jureller, Huang, Grady, Harris, Ganju, Germano, Pilitsis, Pannullo, Benzil, Abosch, Fouke. Reviewed submitted version of manuscript: all authors. Approved the final version of the manuscript on behalf of all authors: Samadani. Statistical analysis: Nieto, Puthenveettil. Study supervision: Samadani.

\section{Supplemental Information}

Previous Presentation

Preliminary data were presented at the 82nd AANS Annual Scientific Meeting held in San Francisco, CA, on April 8, 2014.

\section{Correspondence}

Uzma Samadani, 423 E. 23rd St., MC 112, New York, NY 10010. email: uzma.samadani@nyumc.org. 